\title{
The Social Implications of Some Amharic Proverbs and Their Social Needs for Encouragement
}

\section{Yonas Adamu Chernet}

Lecturer of English Language and Literature, Wolaita Sodo University, Wolaita Sodo, Ethiopia

\section{Email address:}

Yonasadamu6@gmail.com

\section{To cite this article:}

Yonas Adamu Chernet. The Social Implications of Some Amharic Proverbs and Their Social Needs for Encouragement. International Journal of Literature and Arts. Vol. 3, No. 5, 2015, pp. 71-74. doi: 10.11648/j.ijla.20150305.11

\begin{abstract}
The purpose of this Article is to show how the Amharic proverbs use in the society's daily life. Amhara peoples often use proverbs to express the need for people to be courage in whatever they doing in life. This research work focused on the proverbs that Ethiopian Amhara people often use to express courage in people, so as to guarantee better life for them, and of course to make the people to try everything that they want at all times. This research work therefore aim was to exploring the social usage of the proverbs that install motivation in people, within the Amhara people's cultural terrain.
\end{abstract}

Keywords: Proverb, Motivation, Encouragement

\section{Introduction}

The Amhara National Regional State (ANRS) is one of the nine regional states of the Federal Democratic Republic of Ethiopia (FDRE). In geographic terms, the ANRS is located between $9^{0} 21^{\prime}$ to $14^{\circ} 0^{\prime}$ North latitude and $36^{\circ} 20^{\prime}$ and $40^{\circ} 20^{\prime}$ East longitude. The total area of the Amhara region is estimated to be 170,752 square kilometers. The region shares borders with Tigray region in the North, Afar and Oromia regions in the East, Oromia region in the South, and Benishangul region and The Sudan Republic in the West. The region is divided into 11 administrative zones including Bahir Dar special administration (Figure 1) and 114 Woredas. (BoFED2003)

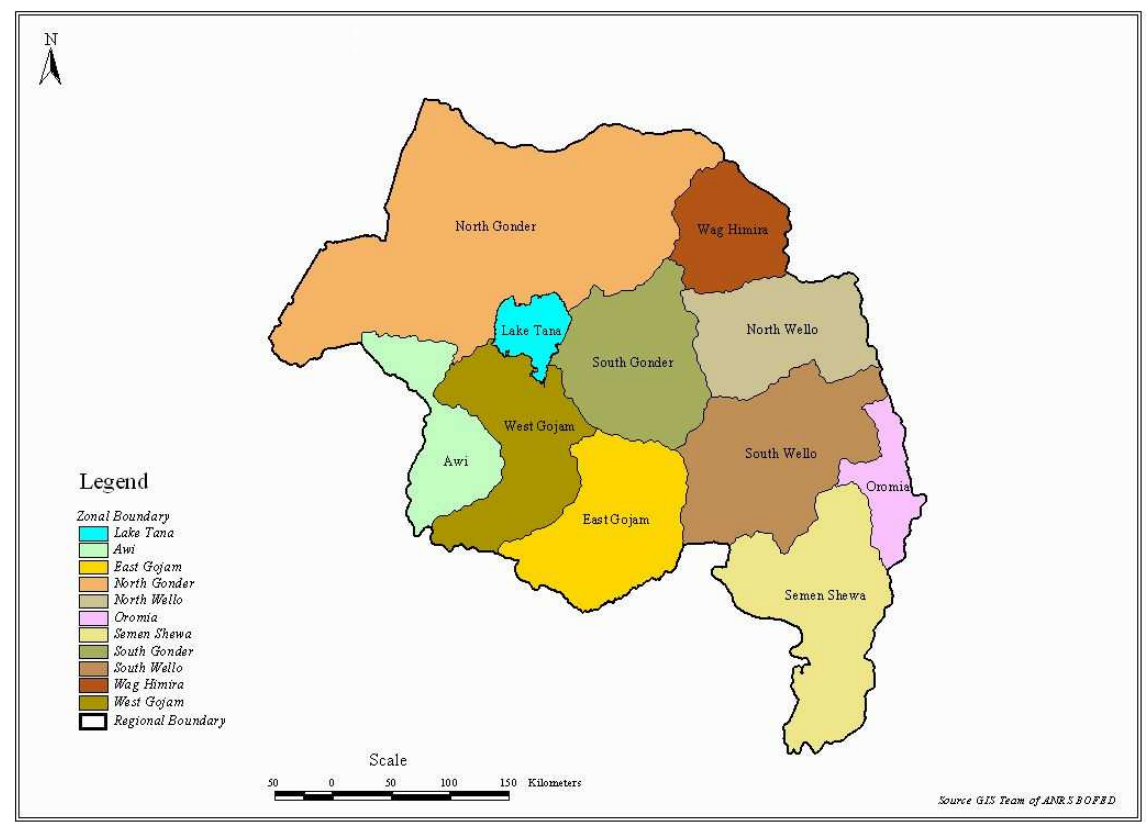

Figure 1. 11 administrative zones including Bahir Dar special administration (Picture) and 114 Woredas. 
The Amhara region had an estimated human population of 19 million for the last Ethiopian fiscal year (BoFED, 2007). These Amhara societies have their own language and alphabets which called Amharic. Amharic is a Semitic language and the national language of Ethiopia. The majority of the 25 million or so speakers of Amharic can be found in Ethiopia, but there are also speakers in a number of other countries, particularly Eritrea.

These Amhara societies have their own proverb which used for different purpose and for different context. The researcher tried to focus on the proverbs which have inspirational or motivational message.

\subsection{Proverb and Motivation}

Motivate implies the act of encouraging and incentive someone for doing some thingregarding issues of life in order to get something and to become successful in life. Without question, the Ethiopian people, particularly the Amhara people believe that it is always good to try something to get some benefits by the avoidance of problems of any sort. To make their idea about motivation in life very vivid and much more impacting, the people of this Ethiopian tribe often use proverbs to imprint on the minds of their fellow people motivation. After such kind of inspiration that people can live fruitful and problem free life.

Proverbs are popular sayings which contain advice or state a generally accepted truth. Because most proverbs have their origins in oral tradition, they are generally worded in such away as to be remembered easily and tend to change little from generation to generation, so much so that sometimes their specific meaning is no longer relevant.

\subsection{Some Common Features of Proverbs}

- $\quad$ Proverbs often make use of grammatical and rhetorical devices that help make them memorable, including alliteration, rhyme, and parallel structure, repetition of key words or phrases, and strong imagery.

- Proverbs are passed down through time with little change in form

- Proverbs transmit from generation to generation orally

(Read Write Think, 2003)

\section{Methodology of the Study}

The study used descriptive research methods. The researcher tried to describe every proverb which is collected from the society by asking elders and by referring some books which are written by focusing on Amharic proverbs. During collecting the proverbs the researcher faced limitation of those proverbs because the researcher had his own specific propose. The researcher tried to collect proverbs which only have motivational and inspirational value for the society.

\section{Result and Discussion}

Some of Amharic Proverbs on Motivate and Incent Peoples to Try Something in Life or Some Amharic inspirational Proverbs

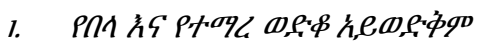 \\ Meaning-When someone learn and eat food, even though he/she fail; he/she can stand.}

Interpretation: The above proverb suggests that for staying in life peoples need food. On the other hand learning is better for life. So Amhara peoples motivate people to do something by mentioning this Amharic proverb. When you eat as the same time you should have to do something to become successful in life. In Ethiopian, especially in Amhara society people motivate each other to start and to do and also to accomplish that work in life for living.

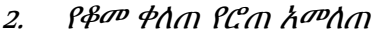

Meaning- The stand one is melt; the runner one is escape.

Interpretation: In Ethiopian society most of the time people waiting things on the place where they are. This is because they may afraid to start that thing or they may wait those things until to come towards them. At that time they lost so many things. Not only they lost those things but also as the same time they lost their hope. So Amhara peoples use this proverb to encourage those peoples who are waiting their dream rather than to go towards their dream.

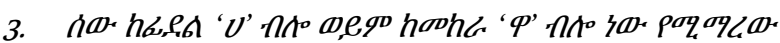 Meaning- Human start learning from letter " $A$ " or from the trouble "shit".}

Interpretation: As all of us know Ethiopian has their letter and their own writing system. So Ethiopian letter start by the letter ' $v$ ' (which spell 'ha') like English language start from letter " $\mathrm{A}$ ". On the other hand when people face problem or trouble they say ' $\boldsymbol{~}$ ' (which spell 'wa') like an English speaker says 'shit'. So Ethiopian people's especially Amhara societies use this proverb to encourage start something and also if the starter fails on the way of doing that thing they tell to him/to her 'you are not loser rather it is a lesson for you'. At that time peoples get courage and try to start doing something bravely. And also peoples develop the attitude of being fail doesn't mean loser rather it is a step-up for their next work.

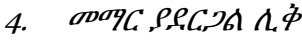 \\ Meaning- Learning makes intelligent.}

Interpretation: Education plays a great role in every society. In Ethiopia, elders peoples advice the younger population to engage their selves in education as much as they can. The society believes that the only get of wisdom is school, so they want everybody to go for learning. At that 
time the learners become intelligent and they can be the persons who lead and manage the country in every aspect. By thinking their final outcome the society motivates the youngsters to go to school for getting knowledge and to being intelligent.

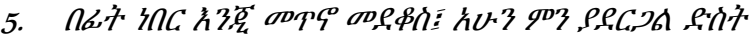 т्र वपूकर}

Meaning: It is better to do things when you can prevent them than to cry when you are already suffering and nothing can be done anymore.

Interpretation: The above proverb shows it seems talking about the past. But the society uses this proverb by fearing the falling of their dears. Amhara society uses this proverb to teach the person that seems fail for the future and they use the proverb like a protector for somebody before he/she fail.

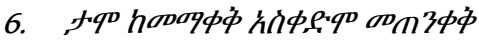

Meaning-Prevention is better than cure

Interpretation: The colloquial meaning of the Amharic proverb is as the researcher stated before "Prevention is better than cure". As it seen clearly if we prevent something before it happens it is easier than treating the happening thing. So Amhara society believes and teaches each other by mentioning this proverb. At that time the peoples try themselves to engage in work and to get something rather than waiting till the poverty makes them sick and kill. As the above proverb, this proverb also focuses on being caring is better than treating the cause. The person who told this proverb tries his/her best to work hard before something happens. So as it mentioned on the above proverbs this proverb also play a great role in the society by motivating the weaker ones to become strong and to develop their working habits.

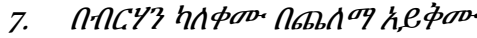

Meaning- It is better using day to collect something, otherwise it is difficult to get it at night.

Interpretation: The above proverb also teaches the society to work hard before getting old and retire. This proverb has a big influence especially for the young population. Because when you are young you have power and strength to do anything that you want but if you are getting ages you can't to do things like the youngsters do. So the person who hears this proverb starts to think about his/her future and he/she starts to think about his/her pension. During that time he/she start working and collecting something for his/her life after work or when he/she getting old.

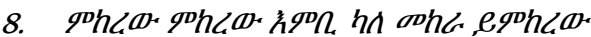

Meaning-Advice and advice him. If he refuses let trouble advise him

Interpretation: The above proverb shows that the person who doesn't listen his/her elder or experienced and professionals advise his/her problem will be advice himself/herself more. But the Amhara society uses this proverb to teach and encourage their people before fall and affected by his/her obstacles. The Amharic speaker people use this proverb for the person who doesn't care about peoples who are thinking for himself/herself. At the same time he/she doesn't not only become careless for them but also for their advice. So this likes of person criticizing by using this proverb and makes him to get a lesson and encouragement.

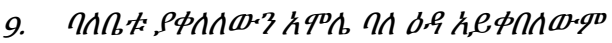

Meaning-A debtor will not accept an amole (salt bar used as currency) if its proprietor has diminished it before.

Interpretation: The above proverb gives a clear message for the peoples who hate work and who has not respect for themselves. In Ethiopia the society believe that self respect is better than anything. This self respect develops through hard working. If the person works hard for his life, He will have value for him/herself. In Amhara society people believe that 'Working gives Pride and Honor'. As a result the society encourages the peoples by using the above proverb.

10. hoqaqla icis oqP.

Meaning-Better to work hard than to be bothered

Interpretation: The other proverb which shows the need of working hard is "Better to work hard than to be bothered". This proverb clearly shows the life of the people who arguing with the government policies and some problems they face on their way of working. Amhara society believes that losing time by complain the system doesn't bring anything. Rather they believe that engaging in work helps and show some direction for changing once life and the whole society living standard.

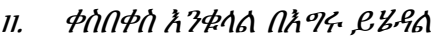

Meaning-Little by little, an egg will walk. Or slowly, slowly, even an egg will walk.

Interpretation: The above proverb gives a good lesson for the hopeless person. Sometimes when a person fails in his first try he/she wants to give up on that work and stay quit. At this time the society says be patient is good. In one night it may be difficult to change things so be patient and try things till the end is better.

\section{Conclusion}

In conclusion, it is indeed germane to say categorically that Amhara people of Ethiopia value the use of proverbs so much, and so often use proverbs as weapon of putting people on the right track in terms of behavior, particularly in making them to realize the fact that hard working is a matter of extreme importance in their lives, so as not to go off course.To the Amhara people getting encouragement about the actions we put up in life is indeed one of the parameters for living a good life. The people of this ethnic group in Ethiopia do have the consciousness that a man or a 
woman who is hard worker in whatever venture in life is one who has a base in wisdom.

\section{References}

[1] Abrams, M.H. (1999). Glossary of Literary Terms. (7th ed.). Cornell University: New York.

[2] Amhara National regional State, Bureau of Agriculture. 1999. Agricultural Research Master Plan (Main Report). Bahir Dar. Ethiopia.

[3] Andrew Bennet and Nicholas Royal (2004). An Introduction to Literature, Criticism and Theory 3rd edition: Great Britain

[4] Hymes, Dell (1972). "Models of the Interaction of Language and social Life" InGumperz and Hymes Directions in SocioLinguistics: The Ethnography of communication. New York: Holt ffinston Rinenart and Winston, Inc.

[5] The Amhara National regional State, Bureau of Finance and Economic Development. 2002/2003 Annual Statistical Bulletin. April 2004. Bahir Dar.

[6] Coulthard, M., and M. Montgomery (1981b). Studies in Discourse Analysis London: Routledge and Kegan Paul.

[7] Levinson, S.C. (1983). Pragmatics Cambridge: Cambridge University Press.
[8] Malinowski, B. (1923). "The problem of Meaning in primitive Languages" in G.K. ogden and I.A Richards (eds.) The Meaning of Meaning

[9] Fekade, A. (2001). The State of Oral Literature Research in Ethiopia: Retrospect and prospect; Journal of Ethiopian Studies: Vol. XXXIV, No 1

[10] Fowler, R. (1973). Dictionary of Modern Critical Terms. Routledge and Kengan Paul Lt.: London.

[11] Meider, Wolfgang. Proverbs Are Never out of Season. New York: Oxford University Press, 1993

[12] Mieder, W. (1999). Proverbs are Never out of Season; Popular wisdom in the modern age. New York: Cambridge University Press.

[13] Ngara, E. (1982). Stylistic Criticism and the African Novel. London: Heinemann

[14] Page, N. (1973). Speech in the English Novel. London: Longman

[15] Searle, J.R. (1969). Speech Acts. Cambridge: Cambridge University Press

[16] Van Dijk, T. (1972). Some Aspects of Text Grammar: A Study in Theoretical Linguistics and Poetics. London: Longman.

[17] Wilkins, D.A. (1972). Linguistics in Language Teaching, London: ELBS and Edward Arnold. 